\title{
A Study on Growth and Productivity of Indian Sugar Companies
}

\author{
Dr.P.Chellaswamy ${ }^{1}$, S.V.Revathi ${ }^{2}$ \\ 1.Assistant Professor,Dept. OF Commerce, Bharathiar University, Coimbatore-641 046, India. \\ 2.Assistant Professor,Dept. OF Commerce WITH CA,Dr.SNS.Rajalakshmi CAS, Coimbatore-641 049, India.
}

\begin{abstract}
Sugar production in India has been cyclic in nature. An estimated 75 per cent of the population depends on the sector either directly or indirectly. Sugar industry is also expected to develop further, thereby offering more employment opportunities to a number of semi-skilled and skilled workers in the rural areas of the country thereby contributing towards their development. The sugar industry also supports diversified ancillary activities and skills that support the local economy. The dependent population creates substantial demand for local goods and services. There are broad areas of public intervention that regulate the sugar market in India. First, both the Central and the State Governments set a price support for sugar cane. Next is by restrictions on sugar quantities to be sold in the market also impose on the sugar factories a so-called sugar levy, by which they are required to sell at below market price to the public distribution centers. There are 34 companies were included for this study among 119 universal companies. The data were appropriately tabulated and classified to analyze the tools like Annual compound growth rate, trend analysis by method of least squares. The productivity ratios and the production function were computed by Solow model. Multiple Regression analysis was used to ascertain its impact on variables and they were tested by $5 \%$ level of significance. The analysis reveals that the relationship between Raw Materials and other independent variables i.e. the Capital, Labour and Sales has contributed 99 percent on dependent variable of the companies which started after green revolution period. The growth of the northern region has positive growth in terms of output, capital employed and also there is better rainfall and irrigation in this region than that of the southern region. The trend line moves towards maximum in BHL companies. The average growth of sugar industry was slower in the southern region than that of northern region due to poor irrigation and rainfall. There is a need for improving the productivity and it can be done by improving the quality of labour compensation such as providing reward to their workers
\end{abstract}

Key Words: Sugar production, sugar industry, Sugar growth, Green revolution, Production Function.

\section{Introduction}

Sugar production in India has been cyclic in nature. An estimated 75 per cent of the population depends on the sector either directly or indirectly. Sugar industry is also expected to develop further, thereby offering more employment opportunities to a number of semi-skilled and skilled workers in the rural areas of the country thereby contributing towards their development. The sugar industry also supports diversified ancillary activities and skills that support the local economy. The dependent population creates substantial demand for local goods and services. The sector also has major social and economic impact on the nation as it is a green industry and is largely self-sufficient in energy needs through utilization of bagasse for generating electricity and steam. In fact, the sugar industry generates surplus exportable energy through cogeneration and contributes to reducing the energy deficit that India is currently facing. Sugar cane is grown in semi-tropical region and accounts for around twothird of world sugar production. Since sugar cane is used as the input for the manufacture of sugar, sugar industry is getting large production from sugar cane growing states in India namely Andhra Pradesh, Tamil Nadu, Gujarat, Karnataka, Maharashtra and Uttar Pradesh.

\section{Statement Of The Problem}

A serious problem for the industry has been its frequent instability. There has been alteration of increases or decreases in production and prices over short periods, resulting in widespread difficulties for producers and consumers. Sugar production in India has fallen, as farmers over years shifted to better paying food crops. The ordinance takes effect from 1974 when the levy pricing of sugar has been a subject of controversy resulting in legal proceedings. There are broad areas of public intervention that regulate the sugar market in India. First, both the Central and the State Governments set a price support for sugar cane. The Central Government announces a price level, referred to as the statuary minimum price for sugar (SMP) raised by State Government to account for differences notably in productivity and transportation cost which was replaced by the concept of Fair and Remunerative Price (FRP), which takes into account "reasonable margins" for growers of sugar cane at which sugar factories are legally required to pay farmers. Next is by restrictions on sugar quantities to be sold in the market also impose on the sugar factories a so-called sugar levy, by which they are required to sell at below market price to the public distribution centers. In addition, the government regulates 
sugar trade via export limitations and marketing restrictions. Hence, the researcher wants to know the answers for the following questions:

1. What is the growth and trend of the sugar companies?

2. What is the productivity of sugar companies in India?

\section{Objectives Of The Study}

1. To study the process of sugar industry.

2. To analyze the Growth and Trend of select sugar companies in India.

3. To study the productivity of select sugar companies in India.

4. To offer findings and suggestions for improving the sugar companies in India.

\section{Methodology And Tools Used}

It is a way to systematically solve the given problem. In order to achieve the objectives the following methodology has been used:

\section{$>$ Sources of data}

The study is mainly based on secondary data through various journals, magazines etc . The most widely-used empowered Capitaline database built by Capital Market India Pvt Ltd, Mumbai forms the source of data.

\section{$>$ Period of the study}

The study covers a period of 10 years from the year 2001-2002 to 2010-2011.

\section{$>$ Sampling Techniques}

The first step in selecting companies has been the identification of a universal set of 119 sugar companies compiled by the Capitaline database of which only 34 sugar companies have financial data available for a continuous period of 10 years from 2001-2002 to 2010-2011. The study proceeded by filtering by the availability of the data, a Convenience sampling technique has been adopted .

\section{LIST OF SELECTED SUGAR COMPANIES}

\begin{tabular}{|c|l|}
\hline S.No & \multicolumn{1}{|c|}{ Name of the company } \\
\hline 1 & Bajaj Hindusthan Ltd \\
\hline 2 & Bannari Amman Sugars Ltd \\
\hline 3 & Dalmia Bharat Sugar \& Industries Ltd \\
\hline 4 & Dharani Sugars \& Chemicals Ltd \\
\hline 5 & Dwarikesh Sugar Industries Ltd \\
\hline 6 & EID Parry (India) Ltd \\
\hline 7 & Empee Sugars \& Chemicals Ltd \\
\hline 8 & Gayatri Sugars Ltd \\
\hline 9 & Girdharilal Sugar \& Allied Industries Ltd \\
\hline 10 & India Sugars \& Refineries Ltd \\
\hline 11 & Indian Sucrose Ltd \\
\hline 12 & Jeypore Sugar Company Ltd \\
\hline 13 & KCP Sugar \& Industries Corporation Ltd \\
\hline 14 & Kesar Enterprises Ltd \\
\hline 15 & KM Sugar Mills Ltd \\
\hline 16 & Kothari Sugars \& Chemicals Ltd \\
\hline 17 & Oudh Sugar Mills Ltd \\
\hline 18 & Parrys Sugar Industries Ltd \\
\hline 19 & Piccadily Agro Industries Ltd \\
\hline 20 & Piccadily Sugar \& Allied Inds Ltd \\
\hline 21 & Ponni Sugars (Erode) Ltd \\
\hline 22 & Prudential Sugar Corporation Ltd \\
\hline 23 & Rajshree Sugars \& Chemicals Ltd \\
\hline 24 & Shree Renuka Sugars Ltd \\
\hline 25 & Simbhaoli Sugars Ltd \\
\hline 26 & Sir ShadiLal Enterprises Ltd \\
\hline 27 & Sri Chamundeswari Sugars Ltd \\
\hline & \\
\hline
\end{tabular}




\begin{tabular}{|l|l|}
\hline 28 & ThiruArooran Sugars Ltd \\
\hline 29 & Triveni Engineering and Industries Ltd \\
\hline 30 & Ugar Sugar Works Ltd \\
\hline 31 & United Provinces Sugar Co Ltd \\
\hline 32 & Upper Ganges Sugar \& Industries Ltd \\
\hline 33 & Venus Sugar Ltd \\
\hline 34 & Vishnu Sugar Mills Ltd \\
\hline
\end{tabular}

For the purpose of the study the selected companies have been classified into different groups on the basis of age and region in which the companies are located.

\section{$>$ Tools of Analysis}

The data were appropriately tabulated and classified to analyze the tools like Annual compound growth rate, trend analysis by method of least squares. The productivity ratios and the production function were computed by Solow model. Multiple Regression analysis were used to ascertain its impact on variables and they were tested by $5 \%$ level of significance.

\section{SCOPE OF THE STUDY}

The present study aims to access mainly the growth and productivity of the select sugar companies in India. In India the growth of the sugar industry plays an important role in achieving its productivity among the world the study is based on accounting information.

\section{NEED OF THE STUDY}

The Indian sugar industry as green industry its future determines the livelihood of millions of farmers. The growth of these companies plays a prominent role in the economic development of the nation. The growth of an industry is based on its success and productivity. It is the primary test of the success of an industry. The consumers and the government are directly or indirectly involved in this industry. If the productivity is more, there will be the technological innovations and the economic will be growth high. The productivity and efficiency mainly depend upon the age and region of the industry. Productivity and better efficiency help to set the industry in the pace of its higher growth. The analysis of productivity has necessities to increase certain industries' economic position. So, this study and an attempt was made to focus its measures by growth and productivity of the companies.

\section{MANUFACTURING PROCESS}

Sugar (sucrose) is a carbohydrate that occurs naturally in every fruit and vegetable. It is a major product of photosynthesis, the process by which plants transform the sun's energy into food. Sugar occurs in greatest quantities in sugarcane and sugar beets from which it is separated for commercial use ${ }^{1}$. The Process of sugar manufacturing from sugarcane to sugar is presented in Chart No:1

CHART No: 1 SHOWING SUGAR MANUFACTURING PROCESS

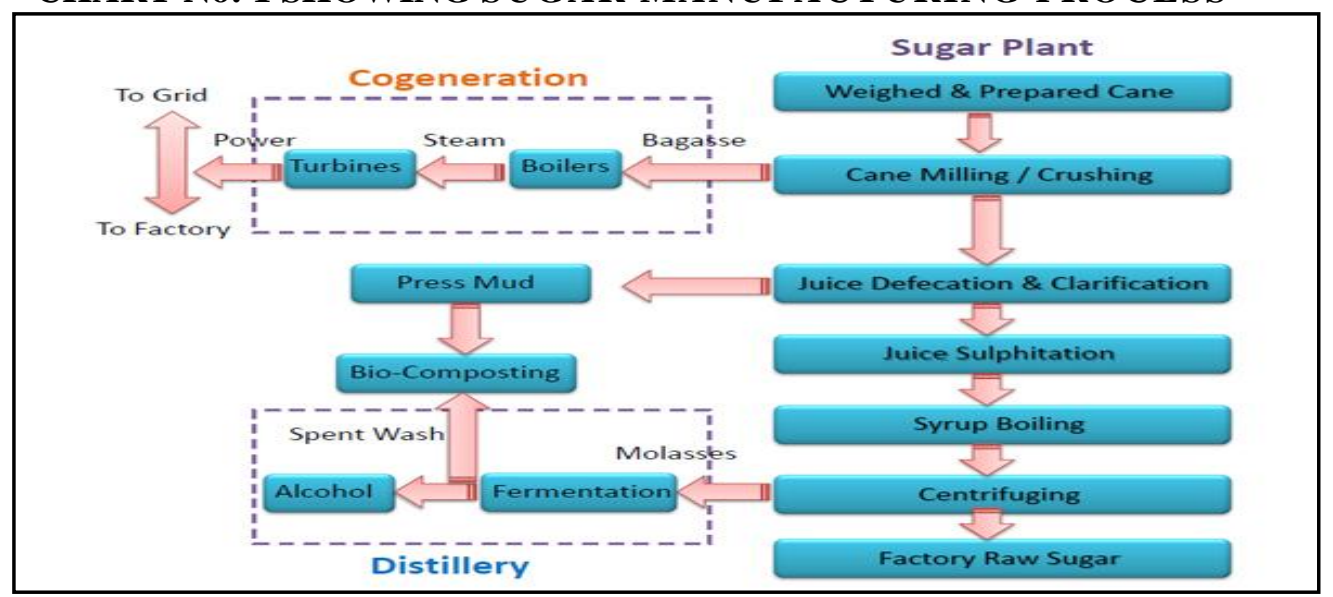

Source: ISMA 2011

1 A Premier Indian International company,2003 
From the chart No: 1 it is inferred that the harvested crops of sugarcane are transported to sugar mills where the mechanical part of the sugar manufacturing process begins. Stalks of sugarcane are usually cleaned of any organic matter, such as dirt or insects, and then washed to make them as sanitized as possible before they are physically changed. This cleaning process is usually done with the aid of a machine, such as a high pressure water jet, and combing drums that sift out larger objects, like rocks. They are cleaned and milled in order for the juice to be extracted. The juice is then both filtered and purified before being boiled. As the juice thickens, it crystallizes, becoming raw sugar. The raw sugar is then spun quickly in a centrifuge, or rotation chamber, in order to fully remove all of the juice and wetness. After that, if the product is being sold as raw sugar, it may be packaged and sent to grocery stores and retail venues for sale. If it is meant to be transformed into refined sugar, it will be sent to a sugar refinery. At a refinery, the raw sugar will be cleaned and drained once again. The refining step of the sugar manufacturing process will then remove all color and non-sugar particles left within the product. From the sugarcane the following contents is prepared ${ }^{2}$ :

- $100 \mathrm{kgs}$ of sugarcane gives approximately $10 \mathrm{kgs}$ of sugar, $5-6 \mathrm{kgs}$ of molasses, $33 \mathrm{kgs}$ of bagasse, and around $4 \mathrm{kgs}$ of press mud.

- $100 \mathrm{kgs}$ of molasses gives 22-25 litres of alcohol and $100 \mathrm{kgs}$ of bagasse can generate 35 units of power.

\section{GROWTH OF SUGAR INDUSTRY IN WORLD REVIEW AND INDIAN REVIEW: INDIAN SUGAR MARKET REVIEW}

From the table No: 1 it is inferred that the sugar production would increase from 13.77 to 31.71 million tons from the period 2004-2005 to 2011-2012.The raw sugar prices also increased from Rs.10360 to Rs.24190 per ton. India's sugar production shows an upswing in production from 2004-2005 to 2007-2008 and there is a decrease in sugar production during 2008-2009 and there is a steady increase in production. The average sugar production is 23.64 million tons with average Raw Sugar price of Rs.17.40 per ton. The standard deviationis 6.95 percent in sugar production with 6.46 percent in raw sugar price. The C.V of sugar production is 0.29 percent as its import is 1.35 percent. The average mean value of import is 1.09 million tons and it is deviated by 1.48 percent stableness.

TABLE No: 1 SHOWS INDIA'S SUGAR PRODUCTION AND IMPORTS

\begin{tabular}{|c|c|c|c|}
\hline YEAR & PRODUCTION(Mt) & IMPORTS(Mt) & $\begin{array}{c}\text { RAW SUGAR } \\
\text { WORLD PRICE('000 INR/t) }\end{array}$ \\
\hline $2004-2005$ & 13.77 & 2.23 & 10.36 \\
\hline $2005-2006$ & 20.94 & 0.00 & 11.61 \\
\hline $2006-2007$ & 30.10 & 0.00 & 12.10 \\
\hline $200-2008$ & 28.88 & 0.00 & 16.14 \\
\hline $2008-2009$ & 15.29 & 2.48 & 25.29 \\
\hline $200-2010$ & 20.45 & 3.70 & 27.44 \\
\hline $2010-2011$ & 28.00 & 0.03 & 20.87 \\
\hline $2011-2012$ & 31.71 & 0.31 & $\mathbf{1 7 . 4 0}$ \\
\hline Mean & $\mathbf{2 3 . 6 4}$ & $\mathbf{1 . 0 9}$ & $\mathbf{6 . 4 6}$ \\
\hline SD & $\mathbf{6 . 9 5}$ & $\mathbf{1 . 4 8}$ & $\mathbf{0 . 3 7}$ \\
\hline CV & $\mathbf{0 . 2 9}$ & $\mathbf{1 . 3 5}$ & \\
\hline
\end{tabular}

Source :Organisation for Economic Cooperation \& Development (OECD) \& Food and Agriculture Organisation (FAO, 2011).

WORLD SUGAR MARKET:

WORLD SUGAR PRODUCTION AND CONSUMPTION

ISMA, Database and news article. 


\section{CHART No: 2 SHOWS WORLD SUGAR PRODUCTION AND CONSUMPTION}

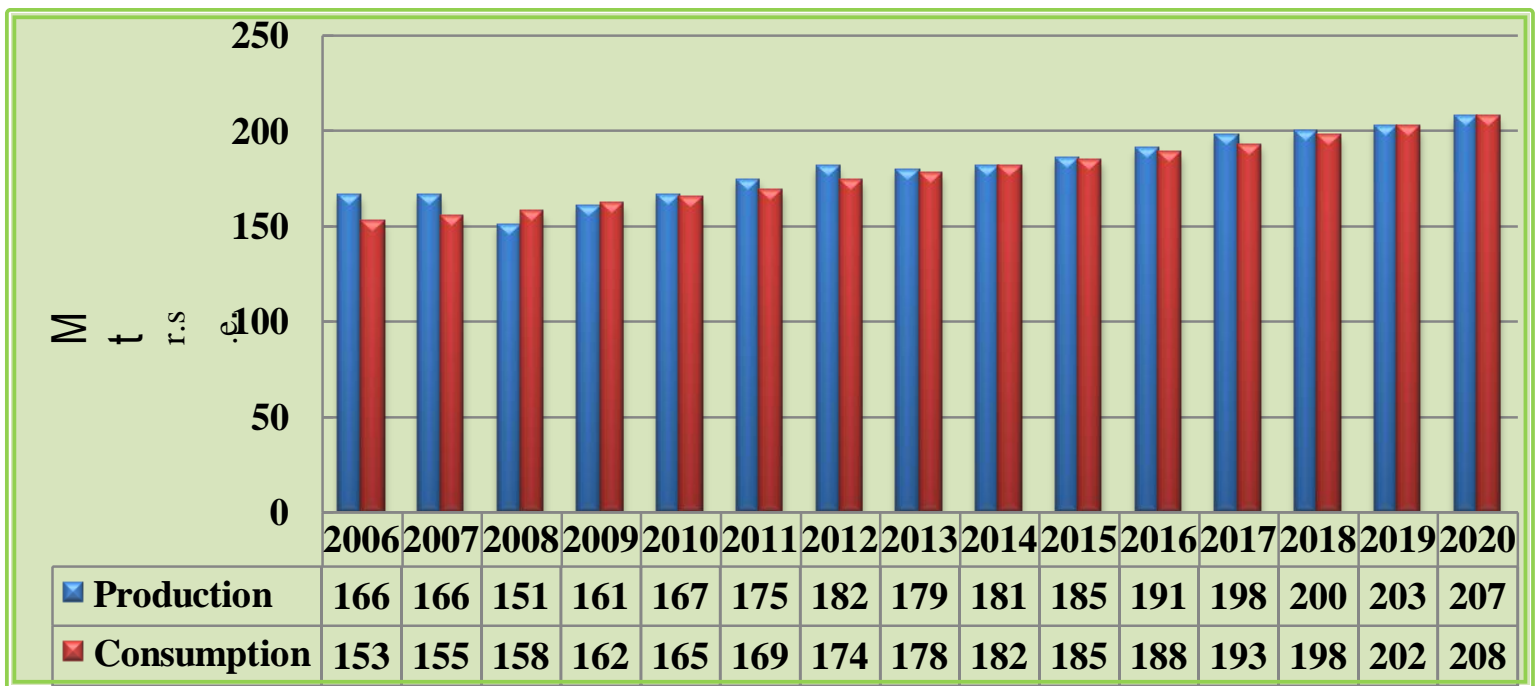
2011.

Source: Organization for Economic Cooperation and Development (OECD) \& Food and Agriculture organization (FAO),

Chart No: 2 shows the Evolution of world sugar production, consumption and stock for the period from 2005-2006 to 2020-2021. It is inferred that the sugar crops in many parts of the world are projected to expand in response to rising demand with relatively high market prices. There is a steady increase in production from the year of period of 2005-2006 to 2020-2021. World sugar production is expected to increase by 50 million tons to reach over 209 million tons in 2020-2021. The bulk of the additional sugar production will come from the developing countries.

ANALYSIS AND INTERPRETATION OF DATA

TABLE No: 2 ANNUAL COMPOUND GROWTH RATE

\begin{tabular}{|l|c|c|c|c|c|}
\hline $\begin{array}{c}\text { COMPANY } \\
\text { NAMEIVAR }\end{array}$ & $\begin{array}{c}\text { NET } \\
\text { WORTH }\end{array}$ & $\begin{array}{c}\text { NET } \\
\text { SALES }\end{array}$ & $\begin{array}{c}\text { PRODUCTIVE } \\
\text { CAPITAL }\end{array}$ & $\begin{array}{c}\text { RAW } \\
\text { MATERIALS }\end{array}$ & $\begin{array}{c}\text { NET } \\
\text { PROFIT }\end{array}$ \\
\hline $\begin{array}{l}\text { Northern } \\
\text { Region }\end{array}$ & 10.22 & 11.73 & 11.21 & 11.85 & 13.38 \\
\hline $\begin{array}{l}\text { Southern } \\
\text { Region }\end{array}$ & 14.57 & 10.50 & 8.39 & 11.25 & 14.29 \\
\hline
\end{tabular}

Source: computed

The above table 2 reveals that annual compound growth rate of select sugar companies in India during the study period from 2001-2002 to 2010-2011. In southern region, the Average Net worth is found to be 14.57 and whereas in northern region is 10.22 which reflects that the asset value relative to liabilities decreases. The Net Sales growth rate is more in the Northern region than that of Southern region and the profit of the Northern region grows at the average annual compound growth of 13.38 percent which implies that the northern region earns more than that of southern region. The raw material consumption was more in the northern region than that of southern region and the productive capital was too high in Northern region.

\section{Trend Analysis For Select Sugar Companies In India}

The trend line is the amount of change in $\mathrm{Y}$ variable that is associated with a change of one unit in $\mathrm{X}$ variable. We can estimate or predict the future behavior of the data by the growth factor. Hence, for this study the Researcher used Method of Least Square in order to analyze the trend value for the future i.e., for the year of 2020-2021.

TABLE No: 3 REVEAL THE TREND ANALYSIS FOR SELECT SUGAR COMPANIES IN INDIA (Rs. In Crores)

\begin{tabular}{|l|c|c|c|c|c|}
\hline $\begin{array}{c}\text { COMPANY } \\
\text { NAME }\end{array}$ & $\begin{array}{c}\text { WORKING } \\
\text { CAPITAL }\end{array}$ & $\begin{array}{c}\text { OPERATING } \\
\text { PROFIT }\end{array}$ & RAW MATERIALS & $\begin{array}{c}\text { NET } \\
\text { SALES }\end{array}$ & $\begin{array}{c}\text { NET } \\
\text { PROFIT }\end{array}$ \\
\hline BHL & 5062.33 & 1597.59 & 4499.83 & 5560.73 & 186.49 \\
\hline BASL & 696.84 & 446.30 & 886.08 & 1797.04 & 289.62 \\
\hline DBSIL & 1400.44 & 1342.82 & 1278.83 & 4349.61 & 472.58 \\
\hline DSCL & 297.19 & 151.40 & 770.65 & 866.71 & 56.85 \\
\hline DSIL & 209.59 & 192.08 & 777.79 & 1068.63 & -1.59 \\
\hline
\end{tabular}


A Study On Growth And Productivity Of Indian Sugar Companies

\begin{tabular}{|c|c|c|c|c|c|}
\hline EPL & 570.00 & 1053.26 & 485.20 & 936.21 & 259.48 \\
\hline ESCL & 187.31 & 18.62 & 81.08 & 129.42 & 12.12 \\
\hline GSL & 73.47 & 15.99 & 88.69 & 140.76 & -12.12 \\
\hline GSAIL & 54.02 & 40.04 & 44.44 & 56.15 & 13.64 \\
\hline ISRL & -25.19 & 2.66 & 28.86 & 66.97 & -2.97 \\
\hline ISL & 179.85 & 51.17 & 188.49 & 263.36 & 14.22 \\
\hline JSCL & -61.76 & 107.08 & 242.45 & 462.11 & 28.92 \\
\hline KSICL & 109.01 & 103.96 & 306.47 & 533.73 & 55.22 \\
\hline KEL & 344.27 & 60.29 & 373.58 & 459.77 & 4.41 \\
\hline KSML & 92.16 & 29.86 & 468.35 & 551.39 & -31.78 \\
\hline KSCL & 139.81 & 79.15 & 529.84 & 681.87 & 67.67 \\
\hline OSML & 371.27 & 136.24 & 901.58 & 1153.81 & -53.17 \\
\hline PSIL & 82.05 & 60.29 & 221.13 & 342.98 & -30.20 \\
\hline PAIL & 51.70 & 48.07 & 203.78 & 304.71 & 21.99 \\
\hline$\overline{\text { PSAIL }}$ & -81.73 & 13.10 & 50.12 & 106.43 & 9.36 \\
\hline$\overline{\mathrm{PSL}}$ & 72.34 & 71.03 & 288.56 & 394.81 & 52.50 \\
\hline$\overline{\mathrm{PSCL}}$ & -3.70 & 0.96 & 137.49 & 157.47 & -4.09 \\
\hline$\overline{\mathrm{RSCL}}$ & 271.58 & 205.38 & 712.85 & 1035.72 & 71.50 \\
\hline$\overline{\text { SRSL }}$ & 1091.50 & 1141.91 & 7094.93 & 8260.92 & 572.34 \\
\hline SSL & 227.96 & 141.82 & 1795.59 & 2163.10 & -36.25 \\
\hline SSLEL & 394.26 & 54.20 & 521.07 & 641.31 & -17.54 \\
\hline$\overline{S C S L}$ & 201.81 & 93.02 & 195.54 & 376.77 & 22.00 \\
\hline TASL & 218.74 & 156.33 & 746.01 & 1151.80 & 48.68 \\
\hline TEIL & 1436.90 & 873.64 & 3384.64 & 5020.06 & 324.22 \\
\hline USWL & 449.25 & 81.70 & 742.57 & 880.72 & -5.70 \\
\hline UPSCL & 114.44 & 26.14 & 207.04 & 253.59 & 2.68 \\
\hline UGSIL & 243.11 & 89.37 & 677.58 & 895.03 & -39.11 \\
\hline VSL & 7.55 & -1.66 & 42.19 & 67.72 & -10.39 \\
\hline VSML & 96.51 & 15.72 & 107.58 & 168.63 & 7.35 \\
\hline
\end{tabular}

Source: computed

The above Table No: 3 show the trend analysis for select sugar companies in India for the year 2020-2021. The Working Capital is maximum in BHL by Rs.5062.33 crores. The negative minimum working capital is found to be in PSAIL by Rs.81.73crores among selected Indian sugar companies. The Operating Profit and it is originated that Rs. 1597.59 crores in BHL would be maximum and the smallest negative amount is found in VSL by Rs.1.66 crores. The Raw Materials consumption is higher in SRSL by Rs.7094.93 crores and the minimum amount is found in ISRL by Rs.28.86 crores. The Net Sales would be maximum in SRSL by Rs.8260.92 crores and the Net sales would be minimum in GSAIL by Rs 56.15 crores. The Net Profit would be greatest in SRSL by Rs.572.34 crores. The minimum negative amount would be in OSML by Rs.53.17 crores among the select sugar companies.

PRODUCTIVITY ANALYSIS FOR SELECT SUGAR COMPANIES IN INDIA: TABLE No: 4 SHOWS PRODUCTIVITY RATIO(Rs. In crores)

\begin{tabular}{|l|c|c|}
\hline Productivity Ratio & $\begin{array}{c}\text { Companies Started } \\
\text { Before Green Revolution }\end{array}$ & $\begin{array}{c}\text { Companies Started } \\
\text { After Green Revolution }\end{array}$ \\
\hline Labour & 1580.79 & 2327.02 \\
\hline Material & 161.13 & 206.91 \\
\hline Capital & 1444.11 & 2620.03 \\
\hline Overall & 1.46 & 1.88 \\
\hline
\end{tabular}

From the table No: 4 it is clear that the labour productivity increases in companies started after green revolution by an average value of Rs. 2327.02 crores. The material production yields minimum in the sugar companies started before green revolution with an average of Rs.161.13 crores. The Capital Productivity ratio is higher in sugar companies started after green revolution by an average value of Rs.2620.03 crores than in sugar companies started before green revolution by Rs.1444.11 crores. The overall productivity was found to be better in companies started after green revolution with an overall average of Rs. 1.88 crores during the period it ranges 
from Rs.2.71 to Rs.1.37 crores.In companies started before green revolution the average value is Rs.1.46 crores during the study period.

\section{PRODUCTION FUNCTIONS USING SOLOW MODEL}

Solow ${ }^{3}$ provided an elementary method of segregating variations in output per head due to technical change from those due to change in the availability of capital per head. The discrete method of measurement of productivity due to Solow model is obtained by

$$
\Delta \mathbf{A}(\mathbf{t}) / \mathbf{A}(\mathbf{t})=\Delta \mathrm{V}(\mathbf{t}) / \mathrm{V}(\mathbf{t})-[\mathrm{SL}(\mathrm{t})(\Delta \mathbf{L}(\mathbf{t}) / \mathbf{L}(\mathbf{t})+\mathrm{SK}(\mathrm{t})((\Delta \mathbf{K}(\mathbf{t}) / \mathbf{K}(\mathbf{t})]
$$

Whereas, $\quad \Delta \mathrm{A}(\mathrm{t}) / \mathrm{A}(\mathrm{t})=$ Annual rates of Total Factor Productivity growth., $\Delta \mathrm{V}(\mathrm{t}) / \mathrm{V}(\mathrm{t})=$ Rate of change of real gross value of production., SL (t) and SK $(\mathrm{t})=$ Share of labour and Share of capital in gross value of production in the year respectively t., $\Delta \mathrm{L}(\mathrm{t}) / \mathrm{L}(\mathrm{t})=$ Rate of change of Labour., $\Delta \mathrm{K}(\mathrm{t}) / \mathrm{K}(\mathrm{t})=$ Rate of change in real gross fixed capital.

TABLE No: 5 SHOWS PRODUCTION FUNCTION INDEX

\begin{tabular}{|c|c|c|}
\hline YEAR & $\begin{array}{c}\text { COMPANIES STARTED BEFORE } \\
\text { GREEN REVOLUTION }\end{array}$ & $\begin{array}{c}\text { COMPANIES STARTED AFTER } \\
\text { GREEN REVOLUTION }\end{array}$ \\
\hline $2001-2002$ & 100 & 100.00 \\
\hline $2002-2003$ & 106.9 & 125.05 \\
\hline $2003-2004$ & 109.1 & 137.14 \\
\hline $2004-2005$ & 92.56 & 131.19 \\
\hline $2005-2006$ & 111.6 & 145.75 \\
\hline $2006-2007$ & 122.4 & 149.85 \\
\hline $2007-2008$ & 104 & 122.27 \\
\hline $2008-2009$ & 101.4 & 109.92 \\
\hline $2009-2010$ & 110.2 & 106.95 \\
\hline $2010-2011$ & 125 & 166.95 \\
\hline MEAN & $\mathbf{1 0 8 . 3}$ & $\mathbf{1 2 9 . 5 1}$ \\
\hline
\end{tabular}

It is seen from the table No: 5 that the production is fluctuating in the sugar companies started before green revolution and it reaches to the maximum accelerating growth in the year 2010 - 2011. In the year 2004 2005 there is a decelerating growth. The mean value Before Green Revolution is 108.3 which results to accelerating growth.The production in the sugar companies started after green revolution is increasing till the financial year 2006-2007 and it further declines in the year 2009-2010. In the year 2010-2011 it reaches to the maximum level of 166.95 percent. The mean value is 129.51 which shows that there is not much variation in the production during the study period. It represents that the growth is accelerating during the study.

\section{MULTIPLE REGRESSION ANALYSIS}

Regression is the measure of the average relationship between two or more variables. When there are two or more independent variables, the analysis that describes such a relationship is multiple regression. This analysis is adapted where there is one dependent variable is function of two or more independent variables. According to Lyman Ott, Michael Longnecker ${ }^{4}$, the multiple regression equation is:

$$
\mathbf{Y}=\mathbf{a}+\mathbf{b}_{1} \mathbf{X}_{1}+\mathbf{b}_{2} \mathbf{X}_{2}+\mathbf{b}_{3} \mathbf{X}_{3}+\ldots . . \mathbf{b}_{\mathbf{n}} \mathbf{X}_{\mathbf{n}}
$$

$\mathrm{Y}$ is the value of the Dependent variable (Y) being predicted, a (Alpha) is the Constant or intercept, $\mathrm{b}_{1}$ is the Slope (Beta coefficient) for $X_{1}, X_{1}$ First independent variable. $b_{n}$ is the Slope (Beta coefficient) for $X_{n}, X_{n} n$ independent variable.

\section{REGRESSION ANALYSIS FOR SUGAR COMPANIES}

Ho1: There is no significant linear relationship between Raw Materials, Capital, Labour, Sales based on Age.

TABLE 6 (a) SHOWS MODEL SUMMARY

\begin{tabular}{|c|c|c|c|c|}
\hline MODEL & R & R Square & $\begin{array}{c}\text { Adjusted } \\
\text { R Square }\end{array}$ & $\begin{array}{c}\text { Std.Error of the } \\
\text { Estimate }\end{array}$ \\
\hline $\begin{array}{c}\text { COMPANIES STARTED } \\
\text { BEFORE GREEN }\end{array}$ & 0.957 & 0.915 & 0.873 & 842.696 \\
\hline
\end{tabular}

3 SOLOW .R.M, "Technical Change and the Aggregate Production Function", Review of Economic and Statistics, vol.36, 1957,p.312.

4 Lyman Ott, Michael Longnecker, "An Introduction to statistical methods and Data Analysis" , Sixth Edition, Macmillian Publishing House, pp.664-722. 


\begin{tabular}{|c|c|c|c|c|}
\hline REVOLUTION & & & & \\
\hline $\begin{array}{c}\text { COMPANIES STARTED } \\
\text { AFTER GREEN } \\
\text { REVOLUTION }\end{array}$ & 0.995 & 0.990 & 0.986 & 231.805 \\
\hline
\end{tabular}

a. Predictors: (Constant), Sales, Capital, Labour

The above table indicates that the companies started before green revolution has the relationship between the dependent variable i.e., Raw Materials and the other independent variables Capital, Labour, Sales which are found to be $0.957(\mathrm{R})$ with $\mathrm{R}$ square 0.915 . It means that all the independent variables have contributed 91.5 per cent on the dependent variable of Raw Materials. It is also found that the companies started after green revolution has $0.995(\mathrm{R})$ with $\mathrm{R}$ square is 0.990 . It means that all the independent variables have contributed 99 percent on the dependent variable of Raw Materials.

TABLE 6 (b) Shows REGRESSION ANOVA

\begin{tabular}{|l|c|c|}
\hline \multicolumn{1}{|c|}{ MODEL } & F & Sig. \\
\hline COMPANIES STARTED BEFORE GREEN REVOLUTION & 21.594 & 0.001 \\
\hline COMPANIES STARTED AFTER GREEN REVOLUTION & 206.664 & 0.000 \\
\hline
\end{tabular}

a. Predictors: (Constant), Sales, Capital, Labour $\quad$ b. Dependent Variable: Raw materials

The above table represents the calculated value of $\mathrm{F}$ is 21.594 for the companies started before green revolution. And the calculated value of $\mathrm{F}$ is 206.664 for the companies started after green revolution. The calculated value which is more than the table value at 5 percent level in both type of companies. So the null hypothesis is rejected and hence the influence of independent variables on the dependent factor is significant.

TABLE 6 (c) SHOWS COEFFICIENTS

\begin{tabular}{|c|c|c|c|c|c|c|}
\hline & & $\begin{array}{c}\text { Unstandardized } \\
\text { Coefficients } \\
\end{array}$ & & $\begin{array}{c}\text { Standardized } \\
\text { Coefficients }\end{array}$ & $\mathbf{t}$ & Sig. \\
\hline Model & & B & Std. Error & Beta & & \\
\hline \multirow{4}{*}{$\begin{array}{l}\text { COMPANIES } \\
\text { STARTED } \\
\text { AFTER } \\
\text { GREEN } \\
\text { REVOLUTION }\end{array}$} & (Constant) & -2173.8 & 404.716 & & -5.371 & 0.002 \\
\hline & Capital & -0.05 & 0.146 & -0.016 & -0.343 & 0.743 \\
\hline & Labour & 10.1947 & 4.431 & 0.290 & 2.301 & 0.061 \\
\hline & Sales & 0.60746 & 0.100 & 0.724 & 6.056 & 0.001 \\
\hline \multirow{4}{*}{$\begin{array}{l}\text { COMPANIES } \\
\text { STARTED } \\
\text { BEFORE } \\
\text { GREEN } \\
\text { REVOLUTION }\end{array}$} & (Constant) & -380.217 & 698.007 & & -0.545 & 0.606 \\
\hline & Capital & -0.522 & 0.534 & -0.140 & -0.977 & 0.366 \\
\hline & Labour & -3.412 & 7.462 & -0.253 & -0.457 & 0.664 \\
\hline & Sales & 0.985 & 0.445 & 1.269 & 2.215 & 0.069 \\
\hline
\end{tabular}

a. Dependent Variable: Raw materials

The above table 6 (c) represents the calculated value of $t$ which is less than the table value at 5 percent level of capital and labour. So the null hypothesis is rejected and hence the influence of independent variables on dependent factor is significant, whereas the Sales value is more than the table value. So the null hypothesis is accepted.

The sales and raw materials have insignificant relationship. It also reveals that the capital has negative effect and the labour and sales have the highest contribution of positive effect in the companies started after green revolution period.

In the companies started before green revolution the calculated value of $t$ which is less than the table value at 5 percent level in capital and labour. So the null hypothesis is rejected and hence the influence of independent variables on the dependent factor is significant, whereas the Sales value is more than the table value and therefore the factor is insignificant. It also reveals that the capital and labour have a negative effect and a sale has the highest contribution of positive effect.

\section{TREND ANALYSIS}

\section{Summary Of Findings}

It is forecasted for the year of 2020-2021 for the select sugar companies in India. The Working Capital is extreme in BHL by Rs.5062.33 crores. The Operating Profit is Rs.1597.59 crores in BHL. The Raw Materials consumption is higher in SRSL by Rs.7094.93 crores. The trend movement is estimated that the Net Sales 
would be maximum in SRSL by Rs. 8260.92 crores. It is found that the Net Profit would be greatest in SRSL by Rs.572.34 crores.

\section{ANNUAL COMPOUND GROWTH ANALYSIS}

The annual compound growth rate of the select sugar companies in India is analyzed based on region. It has been found that the Networth is more in the southern region than that of northern region by 14.57 percent which represents that the funds are utilized at utmost and which in turn increases the investment. The Net Sales is higher in the northern region. It reflects that the profit is effective in the northern region. The productive capital is 11.21 percent in the northern region which is higher than the southern region. The Raw Materials is higher in the northern region than that of southern region by 11.85 percent. It represents the efficient utilization of the material consumption is good in the northern region. The Net Profit is higher in the southern region by 14.29 percent than that of the northern region by 14.29 percent which represent that there a constant eye on the indirect expenses met by the companies in the southern region than that of the northern region.

\section{PRODUCTIVITY ANALYSIS \\ OVERALL PRODUCTIVITY}

The overall productivity was found to be better in the sugar companies started after green revolution in India with an overall average of Rs. 1.88 crores.

\section{FACTORAL PRODUCTIVITY}

The labour productivity increases in the sugar companies started after green revolution by an average value of Rs.2327.02 crores. The material production yields to maximum in the sugar companies started after green revolution with an average of Rs.206.91 crores. The Capital Productivity ratio is high in the sugar companies started after green revolution by Rs.2620.03 crores which implies that these companies performed much better in the use of factoral productivity.

\section{THE PRODUCTION FUNCTIONS USING SOLOW MODEL}

According to Solow production function the mean value in the sugar companies started before green revolution are 108.3 and the mean value of 129.51 in the sugar companies started after green revolution. So the companies which began after green revolution period shows an increase value of production. The growth of sugar companies is accelerating in both cases.

\section{REGRESSION ANALYSIS}

The analysis of multiple regressions reveals that the relationship between Raw Materials and other independent variables i.e. the Capital, Labour and Sales has contributed 99 percent on the dependent variable of the sugar companies which started after green revolution period and the companies which started before green revolution period contribute 91.5 percent.

\section{SUGGESTIONS}

- The trend of working capital of sugar industry in India is found to be negative in ISRL, JSCL, PSAIL, PSCL companies. Therefore, they must improve the working capital position to improve debtors and inventory.

- The average growth of sugar industry was slower in the southern region than that of northern region due to poor irrigation and rainfall.

- There is a need for improving the productivity and it can be done by improving the quality of labour compensation such as providing reward to their workers.

- The sugar companies started before green revolution should increase production with the up gradation of modern technological innovation.

- Material accounts for nearly 80 percent of cost of production. It constitutes a significant part of production cost and therefore proper planning, purchasing, handling and accounting of material are of great importance.

\section{Conclusion}

The study brings out the fact that the production of sugar in the companies started after green revolution is more effective than the sugar companies started before green revolution. It is due to the effective utilization and modernization of its resources. The analysis reveals that the relationship between Raw Materials and other independent variables i.e. the Capital, Labour and Sales has contributed 99 percent on dependent 
variable of the companies which started after green revolution period. The growth of the northern region has positive growth in terms of output, capital employed and also there is better rainfall and irrigation in this region than that of the southern region. The trend line moves towards maximum in BHL companies.

\section{BOOKS:}

[1]. Beri, G.C, "Measurements of Production and Productivity in Indian Industry", Asia Publishing House, London, 1962.

[2]. Gupta.S.P, "Statistical Methods", Sultan Chand \& Sons Publishing, New Delhi, 2005.

[3]. Kothari, C.R., "Research Methodology - Methods and Techniques", Wiley Eastern Ltd, New Delhi,2004,

[4]. Michael, V.P., "Research Methodology in Management" Himalayan Publishing House, Bombay, 1985.

[5]. Ramasamy, K.V, "Productivity of the Indian Manufacturing Industries", Print Well Publishers, Jaipur, 1996.

[6]. Agarwal, "Technical Efficiency and the Productivity Growth in the Central Public Sector Enterprises in India", Economic and Political Weekly, 2001.

[7]. Balakrishnan, R, "Productivity Measurement in Indian Industry" Madras university press, 1958.

[8]. Banerjee, A., "Capital Intensity and Productivity in Indian Industries", MacMillian Publications, New Delhi, 1975.

[9]. Brown and Decani, "Technological Changes can be Measured through the Simple Ratios and through Production Approach", National Bureau of Economic Research, Princeton University press, 1962.

\section{JOURNALS:}

[10]. ISMA, Database and news article.

[11]. Neil \& Young, 1979, “The economics of multinational Enterprises Long man”, London, p.2.

[12]. Baumol U.J., 1982, "Theory of the expansion of the firm", American Economic Review, Vol-72, No.5, pp-1078-1087.

[13]. Solow, 1956, “A Contribution to the theory of the economic growth", Quarterly Journal of Economics, Feb, Vol.XV, No.2, P.101 and Meade, 1962, “A Neo-Classical theory of economic growth”, Unwin University books, London.

[14]. SOLOW .R.M, "Technical Change and the Aggregate Production Function", Review of Economic and Statistics, vol.36, 1957,p.312.

[15]. Lyman Ott, Michael Longnecker, "An Introduction to statistical methods and Data Analysis”, Sixth Edition, Macmillian Publishing House, pp.664-722. 